\title{
CORRESPONDENCE
}

\section{Evolution in meaning of certain geological terms}

SIR,-When reviewing recently for Departmental purposes some of the literature on pillow lavas, I was particularly struck by the way in which the meaning of the word 'spilite' had changed completely during the course of a century-and-a-half. Nowadays, 'spilite' readily connotes firstly albitized basalt and, secondly, pillow lava itself. It will be recalled that Dewey \& Flett $(1911$, p. 209) recognized the 'spilitic suite' of soda-rich rocks characterized by albitization of plagioclase, and (p. 202) pointed out the adoption by the Geological Survey of the term 'spilite' to denote Ordovician, Devonian and Carboniferous pillow lavas of Devon and Cornwall. Earlier, however, Kemp (1906, p. 204) had declared simply that spilite was '. . . an early French name for dense, amygdaloidal varieties of diabase'. Bonney \& Raisin (1893, pp. 59-64) were concerned neither with particular chemical composition nor with pillow structure, but wished to demonstrate that the '. . . so-called spilites of Jersey' were in fact flows and agglomerates (rather than metamorphosed argillites as Noury had claimed). Brongniart also (1827, p. 98), had defined spilite without reference either to distinctive chemical composition or to the development of pillow structure, as 'Pâte d'Aphanite, renfermant des noyaux et des veines calcaires contemporains ou postérieurs à la pâte' and with 'structure empâtée'. Most of his examples are of rocks with amygdaloidal or porphyritic texture.

Recently, a similar sort of major change, apparently without anyone much noticing, seems to have been taking place in the meaning of 'ophiolite'. Earlier, 'ophiolite' would seem to have referred specifically to peridotites. Kemp (1906, p. 210) quoted ophiolite as 'Brongniart's name for the serpentines', and forty-one years later Umbgrove (1947, $\mathrm{p}$. 81) still spoke of 'dunite or serpentinised peridotite (also called ophiolite)'. Heritsch (1929, in Boswell's translation, p. 56) referred to '... ophiolitic eruptive rocks (that is, spilite, variolite, diabase-porphyrite, gabbro, serpentinite and ophicalcite) ... M Miyashiro (in Hess \& Poldervaart, 1968, p. 826) declared, quoting Tyrrell, that 'Ophiolites include peridotite, gabbro, spilite and basalt along with their metamorphic derivatives' and went on to mention 'Steinmann's trinity', following a reference to Steinmann $(1905,1927)$ as having emphasized the association of ophiolites with radiolarian cherts, while Hess (1955) and Bailey \& McCallien (1960) were quoted as having the trinity consist of serpentine, spilite and radiolarian chert. Bailey \& McCallien (1960, pp. 369-95) did not actually use the term 'ophiolite', but the implication is clear that 'ophiolite' includes serpentine (serpentinite) and spilite.

Thus far, it seems fairly evident that we are to consider 'ophiolite' as including not only basic but also ultrabasic rocks. Recently, however, Harland (1967, p. 186) has, albeit perhaps inadvertently, highlighted a change which seems to be creeping into the terminology, by referring to the Steinmann trinity as consisting of ophiolite, radiolarite and serpentine (my italics). A separation of serpentinite from ophiolite was also made by Crooke (1969, p. 435) who has stated that, in a certain situation, ophiolites are only doubtfully represented, whereas serpentinites definitely occur. We seem, therefore, likely to be faced with a situation where 'ophiolite', which once included ultrabasic rocks, is to come to mean an 'ophiolite suite' with ultrabasic rocks excluded. In this connection we may note that the American Geological lnstitute (1962, p. 355) described ophiolite as 'basic igneous rock associated with geosynclinal sediments'.

If, as Miyashiro (in Hess \& Poldervaart, 1968, p. 826) believed, the term ophiolite ‘. . has real genetic significance...' it evidently behoves us to try to give, currently, some precision to its meaning. At what stage is the apparent evolution in the meaning of the word to stop, or be stopped, and in what way?

\section{References}

American Geological Institute. 1962. Dictionary of Geological Terms. 545 pp. Doubleday, New York. 
Bailey, E. B. \& McCallien W. J. 1960. Some aspects of the Steinmann Trinity, mainly chemical. Q. Jl geol. Soc. Lond. 116, 369-95.

Bonney, T. G. \& Raisin C. A. 1893. On the so-called spilites of Jersey. Geol. Mag. 10, 59-64.

Brongniart, A. 1827. Classification et caractères minéralogiques des roches homogènes et hétérogènes. F. G. Levrault, Paris.

Crooke, K. A. W. 1969. Contrasts between Atlantic and Pacific geosynclines. Earth and Planetary Science Letters 5, 429-38.

Dewey, H. \& Flett, J. G. 1911. On some British pillow lavas and the rocks associated with them. Geol. Mag. 8, 202-9 and 241-8.

Harland, W. B. 1967. Geosynclines. Geol. Mag. 104, 182-8.

Heritsch, F. 1929. The Nappe Theory in the Alps. 228 pp. Methuen, London.

Hess, H. 1955. Serpentines, orogeny and epeirogeny, pp. 391-408 in Hess, H. H. \& Poldervaart, A. (Eds.): Crust of the Earth. 762 pp. Geological Society of America Special Paper, 62.

Hess, H. \& Poldervaart, A. 1968. Basalts, the Poldervaart Treatise on Rocks of Basaltic Composition. 862 pp. Interscience Publishers, New York.

Kemp, J. F. 1906. A Handbook of Rocks, for use without the microscope. $238 \mathrm{pp}$. Van Nostrand, New York.

Miyashiro, A. 1968. Metamorphism of Mafic Rocks, pp. 799-834 in Hess, H. H. \& Poldervaart, A. (Eds.): Basalts, the Poldervaart Treatise on Rocks of Basaltic Composition. 862 pp. Interscience Publishers, New York.

Steinmann, G. 1905. Geologische Beobachtungen in den Alpen. II. Die Schartdtsche Ueberfaltungstheorie und die geologische Bedeutung der Tiefseeabsätze und der ophiolithischen Massengesteine. Ber. Naturfor. Gesellsch. Freiburg i.B. 16, 18-67. 1927. Die ophiolithischen Zonen in der mediterranean Kettengebirgen. 14th Int. geol. Congr., Madrid, C.R. 2, 638-67.

Umbgrove, J. H. F. 1947. The Pulse of the Earth. 358 pp. Nijhoff, the Hague.

Geological Survey Department

Derek Green

Private Bag, G.P.O.

Suva, Fiji.

1 st December 1970. 